\title{
PELATIHAN PERMAINAN TONNIS BAGI GURU PENJASORKES SD DAN SMP SE-KABUPATEN JEMBRANA
}

\author{
oleh, \\ Made Agus Wijaya \\ Fakultas Olahraga dan Kesehatan \\ Universitas Pendidikan Ganesha
}

\begin{abstract}
ABSTRAK
Tujuan kegiatan pengabdian ini adalah memberikan pengetahuan, pemahaman dan keterampilan kepada guru penjasorkes SD dan SMP se-Kabupaten Jembrana tentang permainan tonnis melalui pelatihan. Pelatihan dilaksanakan tepatnya pada Jumat, 26 Juli 2013 di SMP Negeri 4 Mendoyo-Jembrana, mulai pukul 08.30 sampai dengan 16.00 wita. Peserta yang berpartisipasi aktif pada pengabdian kepada masyarakat (P2M) ini berjumlah 61 orang, berasal dari Guru Penjasorkes SD dan SMP se-Kabupaten Jembrana. Metode yang digunakan dalam kegiatan P2M ini adalah metode praktek yang disertai dengan ceramah dan diskusi. Pelaksanaan kegiatan berlangsung dengan lancar.. Peserta nampak semangat dan antusias selama kegiatan pemaparan materi dan praktek permainan tonnis.
\end{abstract}

Kata-kata kunci: pelatihan, permainan tonni

\begin{abstract}
The objectives of this service is to provide the knowledge, understanding and skills to elementary and junior high school teachers penjasorkes se-Jembrana about the game tonnis through training. Training is conducted precisely on Friday, July 26th, 2013 at SMP Negeri 4 Mendoyo-Jembrana, starting at 08:30 until 16:00 pm. Participants who participate actively in community service (P2M) numbering 61 people, derived from primary and secondary school teachers Penjasorkes se-Jembrana. The method used in this P2M activity the practice of method and discussion. Implementation of activities went on smoothly .. The participants seem passion and enthusiasm for the activities and practice material exposure tonnis game.
\end{abstract}

Keywords: training, tonni game 


\section{Pendahuluan}

Pendidikan jasmani, olahraga dan kesehatan (penjasorkes) merupakan salah satu mata pelajaran (mapel) wajib yang harus diberikan pada pada siswa jenjang pendidikan dasar dan Menengah. Hal tersebut tertuang dengan jelas pada Undang-Undang Republik Indonesia Nomor 20 Tahun 2003 tentang Sistem Pendidikan Nasional (Sisdiknas) Pasal 37 Ayat 1. Tertuangnya mapel penjasorkes tersebut menandakan pemerintah menaruh perhatian yang besar bahwa melalui mapel penjasorkes siswa mampu mencapai tujuan pendidikan nasional yaitu berkembangnya potensi siswa agar menjadi manusia yang beriman dan bertakwa kepada Tuhan Yang Maha Esa, berakhlak mulia, sehat, berilmu, cakap, kreatif, mandiri, dan menjadi warga negara yang demokratis serta bertanggung jawab.

Penjasorkes yang diberikan di sekolah memiliki peranan sangat penting, yaitu memberikan kesempatan kepada peserta didik untuk terlibat langsung dalam berbagai pengalaman belajar melalui aktivitas jasmani, olahraga dan kesehatan yang terpilih yang dilakukan secara sistematis. Pembekalan pengalaman belajar itu diarahkan untuk membina pertumbuhan fisik dan pengembangan psikis yang lebih baik, sekaligus membentuk pola hidup sehat dan bugar sepanjang hayat. Pendidikan memiliki sasaran pedagogis, oleh karena itu pendidikan kurang lengkap tanpa adanya penjasorkes, karena gerak sebagai aktivitas jasmani adalah dasar bagi manusia untuk mengenal dunia dan dirinya sendiri yang secara alami berkembang searah dengan perkembangan zaman. Namun kenyataan di lapangan terjadi khususnya pada pelaksanaan pembelajaran penjasorkes bahwa siswa seringkali terbatas geraknya. Keterbatasan gerak siswa ini apabila tidak segera diberikan solusi akan berdampak pada rendahnya derajat kebugaran jasmani siswa.

Berdasarkan pengamatan pengusul dan dikuatkan dengan informasi dari Ketua Musyawarah Guru Mata Pelajaran (MGMP) Penjasorkes SMP se-Kabupaten Jembrana, pada umumnya sekolah hanya memiliki lahan bermain seluas lapangan bulutangkis. Keterbatasan lapangan ini harus dimanfaatkan secara optimal oleh guru penjasorkes dalam membelajarkan siswa sehingga siswa mampu mencapai tujuan belajar yang optimal pula. Gerak dalam pembelajaran penjasorkes di sekolah dasar diimplementasikan melalui kegiatan bermain. Untuk itu guru penjasorkes dituntut 
inovasi dan kreativitasnya membelajarkan permainan pada siswa yang dapat dilakukan pada lapangan seluas lapangan bulutangkis.

Hal tersebut disikapi dengan cermat, sehingga dikembangkanlah permainan tonnis oleh Bapak Triharsono dan Sri Haryono dari Universitas Negeri Semarang. Tonnis merupakan permainan yang memadukan unsur bulutangkis (badminton) dan tenis lapangan karena dimainkan dalam lapangan seukuran lapangan bulutangkis dan teknik bermain seperti tenis lapangan. Dalam permainan tonnis dibutuhkan komponen pengembangan pribadi individu yaitu kognitif, afektif dan psikomotor. Disisi lain permainan tonnis memiliki nilai praktis, ekonomis atau murah dan memberikan kesenangan dan kepuasan bagi semua tingkat usia yang memainkannya.

Permainan tonnis dapat dilakukan oleh semua tingkatan usia baik laki-laki maupun perempuan. Peralatan yang digunakan adalah alat pemukul (selanjutnya disebut paddle) dan bola tenis yang gembos. Paddle terbuat dari bahan kayu yang ringan tetapi kuat atau tidak mudah patah seperti papan multipleks dengan ketebalan 8-12 mm. Pegangan paddle diisi dengan tali dengan tujuan menjaga paddle tetap pada genggaman tangan sehingga pemain merasa aman dan nyaman tidak takut apabila paddle terlepas dari genggaman. Peraturan permainan tonnis hampir sama dengan tenis lapangan yang menyangkut tentang servis, point dan game, bola masuk dan bola keluar.

Biaya yang dibutuhkan untuk melaksanakan permainan tonnis lebih murah dibandingkan dengan permainan bulu tangkis ataupun futsal. Ditinjau dari segi lapangan, antara permainan bulu tangkis, futsal dan tonnis dapat dimainkan dalam lapangan seukuran 13,10 meter x 6,10 meter. Permainan futsal membutuhkan biaya yang mahal untuk dapat memainkannnya misalnya memberi bola futsal kulit dan sepatu futsal, belum lagi apabila ingin bermain pada lapangan futsal yang berumput sintetis dengan biaya sewa rata-rata Rp. 100.000 per jam. Demikian halnya dengan permainan bulu tangkis, membutuhkan biaya yang mahal untuk membeli raket bulu tangkis berbahan titanium dan shuttlecock yang banyak dan cepat rusak bila bandingkan dengan bola pada permainan tonnis. Dalam permainan tonnis biaya yang dibutuhkan lebih murah, paddle dibuat dengan papan multipleks lebih murah dibandingkan dengan raket bulutangkis berbahan titanium. Sedangkan bola yang digunakan dalam permainan tonnis dapat menggunakan bola tenis setengah pakai yang sudah gembos dan gundul. 
Permainan tonnis ini belum banyak dikenal oleh guru penjasorkes khususnya di Kabupaten Jembrana. Melalui program pengabdian pada masyarakat ini, kami bermaksud menyelenggarakan pelatihan permainan dan peraturan Tonnis bagi Guru Penjasorkes SD dan SMP se-Kabupaten Jembrana.

\section{Metode Kegiatan Pengabdian.}

Ciri keberhasilan suatu hasil karya ilmiah dapat dilihat dari cara/metode penyelesaian suatu permasalahan. Seberapa besar pemecahan masalah yang dapat dilakukan dapat dilihat dari manfaat yang ditimbulkan untuk dapat dinikmati oleh orang lain (guru penjasorkes dan siswa). Semakin besar manfaat yang diberikan semakin berhasil pula hasil solusi yang diberikan atau yang telah diciptakan. Begitu pula dengan karya tulis Pengabdian pada Masyarakat $\left(\mathrm{P}_{2} \mathrm{M}\right)$ ini, solusi yang ditawarkan berdasarkan permasalahan mitra dapat diidentifikasi seperti Tabel 01 berikut.

Tabel 01. Identifikasi Permasalahan Mitra dan Solusi yang ditawarkan

\begin{tabular}{|c|c|}
\hline Permasalahan Mitra & Solusi yang Ditawarkan \\
\hline $\begin{array}{l}\text { 1. Terbatasnya lapangan bermain } \\
\text { yang dimiliki sekolah khususnya } \\
\text { sekolah dasar yang pada } \\
\text { umumnya hanya memiliki } \\
\text { lapangan seukuran lapangan } \\
\text { bulutangkis }\end{array}$ & $\begin{array}{l}\text { 1. Memanfaatkan fasilitas umum terutama } \\
\text { lapangan terdekat dengan sekolah } \\
\text { sebagai tempat pelaksanaan } \\
\text { pembelajaran penjasorkes. } \\
\text { 2. Mengoptimalkan lapangan yang ada } \\
\text { dengan mengelola pembelajaran secara } \\
\text { berkelompok dan bergantian } \\
\text { melakukan tugas gerak. }\end{array}$ \\
\hline $\begin{array}{l}\text { 2. Terbatasnya pemahaman dan } \\
\text { pengetahuan guru penjasorkes } \\
\text { terhadap permainan-permainan } \\
\text { yang dapat dilakukan pada } \\
\text { lapangan seukuran lapangan } \\
\text { bulutangkis }\end{array}$ & $\begin{array}{l}\text { 1. Mengikuti kegiatan ilmiah dalam } \\
\text { bentuk seminar, lokakarya dan atau } \\
\text { workshop tentang pembelajaran } \\
\text { penjasorkes. Melalui forum ini dapat } \\
\text { disampaikan permasalahan- } \\
\text { permasalahan yang dihadapi terkait } \\
\text { pembelajaran penjasorkes sehingga } \\
\text { memperoleh alternatif solusinya. } \\
\text { 2. Mencari dan mengidentifikasi jenis- } \\
\text { jenis permainan permainan yang dapat } \\
\text { dilakukan pada lapangan seukuran } \\
\text { lapangan bulutangkis melalui buku }\end{array}$ \\
\hline
\end{tabular}




\begin{tabular}{|l|l|}
\hline Permasalahan Mitra & \multicolumn{1}{|c|}{ Solusi yang Ditawarkan } \\
\hline & sumber, perpustakaan dan internet. \\
& Permainan yang dapat dilakukan pada \\
& lapangan seukuran lapangan \\
& bulutangkis antara lain permainan \\
& hadang (gobak slodor), permainan \\
& kejar-kejaran (magoak-goakan) dan \\
& permainan tonnis. \\
\hline
\end{tabular}

Oleh karena itu, permasalahan yang hendak dijawab melalui program pengabdian pada masyarakat khususnya bagi Guru Penjasorkes SD dan SMP se-Kabupaten Jembrana ini adalah: (1) Bagaimanakah proses pelatihan permainan tonnis bagi Guru Penjasorkes SD dan SMP se-Kabupaten Jembrana?, (2) Bagaimanakah aplikasi peraturan permainan tonnis melalui simulasi pertandingan Guru Penjasorkes SD dan SMP se-Kabupaten Jembrana?

Untuk menjawab permasalahan di atas, maka metode yang dipergunakan dalam kegiatan Pengabdian pada Masyarakat ini adalah : (1) Metode ceramah yaitu menyampaikan materi permainan tonnis yang mencakup hakikat bermain tonnis, fasilitas dan alat bermain tonnis, peraturan permainan tonnis, teknik dasar tonnis serta metode latihan tonnis, (2) Metode pelatihan yaitu guru berlatih untuk berlatih teknik dasar tonnis, bermain tonnis, dan berlatih membelajarkan tonnis kepada siswa, dan (3) Metode diskusi yaitu melakukan diskusi pada saat penyampaian materi, praktek lapangan maupun simulasi permainan tonnis.

\section{Hasil dan Pembahasan.}

Berlandaskan rencana dan jadwal kerja $\mathrm{P}_{2} \mathrm{M}$ pelatihan permainan tonnis bersama ini dapat kami paparkan hasil dan pembahasan kegiatan sebagai berikut: Kegiatan yang dilakukan pada tahap ini secara garis besar meliputi 4 (empat) kegiatan yaitu:1) mengadakan observasi, 2) penyusunan proposal $\mathrm{P}_{2} \mathrm{M}$, 3) mengikuti seminar proposal dan 4) melaksanakan revisi proposal. Setelah mengadakan observasi dan penyusunan proposal $\mathrm{P}_{2} \mathrm{M}$, ketua pelaksana mengikuti seminar proposal dengan reviewer Dr. rer.nat. I Wayan Karyasa, S.Pd., M.Sc. dan Drs. Nyoman Subrata, M.Si. Kedua reviewer memberikan saran, masukan serta pertanyaan untuk selanjutnya menjadi 
pertimbangan ketua pelaksana dalam melakukan revisi proposal. Berdasarkan hasil seleksi seminar proposal $\mathrm{P}_{2} \mathrm{M}$, LPM Undiksha menentukan proposal $\mathrm{P}_{2} \mathrm{M}$ dengan judul Pelatihan Permainan Tonnis bagi Guru Penjasorkes SD dan SMP se-Kabupaten Jembrana menjadi salah satu proposal $\mathrm{P}_{2} \mathrm{M}$ yang didanai dari dana PNBP Undiksha Tahun 2013.

Setelah pengumuman hasil seminar proposal $\mathrm{P}_{2} \mathrm{M}$, ketua pelaksana kegitan bersama ketiga anggota pelaksana selanjutnya melaksanakan tahapan pelaksanaan kegiatan. Pada tahap ini, kegiatan yang dilaksanakan terdiri atas 6 (enam) kegiatan utama yaitu: 1) melakukan penjajagan ke SD dan SMP se-Kabupaten Jembrana, 2) pengurusan izin melaksanakan $\mathrm{P}_{2} \mathrm{M}$ ke Bupati Jembrana, Dinas Pendidikan Kabupaten. Jembrana, Kepala UPP Kabupaten Jembrana dan Unit $\mathrm{P}_{2} \mathrm{M}$ Undiksha, 3) penyebaran undangan sebagai peserta pelatihan, 4) menyiapkan materi pelatihan, alat, gedung dan lapangan, 5) melaksanakan kegiatan dan 6) monitoring dan evaluasi. Berikut ini disajikan data pelaksananaan ke enam kegiatan pada tahap pelaksanaan kegiatan.

Tabel 02. Waktu dan Tempat Tahap Pelaksanaan Kegiatan $\mathrm{P}_{2} \mathrm{M}$

\begin{tabular}{|c|c|c|c|}
\hline No & Kegiatan & Waktu & Tempat \\
\hline 1. & $\begin{array}{l}\text { Melakukan penjajagan ke SD dan } \\
\text { SMP se-Kabupaten Jembrana }\end{array}$ & $\begin{array}{c}1-5 \mathrm{Juli} \\
2013\end{array}$ & $\begin{array}{l}\text { SD dan SMP di } \\
\text { Jembrana }\end{array}$ \\
\hline 2. & $\begin{array}{l}\text { Pengurusan izin melaksanakan } \mathrm{P}_{2} \mathrm{M} \\
\text { ke Bupati Jembrana, Dinas } \\
\text { Pendidikan Kabupaten. Jembrana, } \\
\text { Kepala UPP Kabupaten Jembrana } \\
\text { dan Unit } \mathrm{P}_{2} \mathrm{M} \text { Undiksha }\end{array}$ & $\begin{array}{c}5-10 \text { Juli } \\
2013\end{array}$ & $\begin{array}{l}\text { Bupati Jembrana, } \\
\text { Dinas } \\
\text { Dikporaparbud } \\
\text { Kabupaten } \\
\text { Jembrana, LPM } \\
\text { Undiksha }\end{array}$ \\
\hline 3. & $\begin{array}{l}\text { Penyebaran undangan sebagai } \\
\text { peserta pelatihan kepada Kepala } \\
\text { Sekolah SD dan SMP se-Kabupaten } \\
\text { Jembrana }\end{array}$ & $\begin{array}{c}12-25 \text { Juli } \\
2013\end{array}$ & $\begin{array}{l}\text { SD dan SMP se } \\
\text { Kabupaten } \\
\text { Jembrana }\end{array}$ \\
\hline 4. & $\begin{array}{l}\text { Menyiapkan materi pelatihan, alat, } \\
\text { gedung dan lapangan }\end{array}$ & $\begin{array}{c}12-25 \text { Juli } \\
2013\end{array}$ & $\begin{array}{l}\text { FOK Undiksha } \\
\text { dan GOR SMP } \\
\text { Negeri } 4 \\
\text { Mendoyo- } \\
\text { Jembrana }\end{array}$ \\
\hline 5. & Melaksanakan kegiatan & 26 Juli 2013 & $\begin{array}{l}\text { GOR SMP Negeri } \\
4 \text { Mendoyo- }\end{array}$ \\
\hline
\end{tabular}




\begin{tabular}{|l|l|l|l|}
\hline No & \multicolumn{1}{|c|}{ Kegiatan } & \multicolumn{1}{|c|}{ Waktu } & \multicolumn{1}{|c|}{ Tempat } \\
\hline & & & Jembrana \\
\hline 6. & Monitoring dan evaluasi & 26 Juli 2013 & $\begin{array}{l}\text { GOR SMP Negeri } \\
\text { 4 Mendoyo- } \\
\end{array}$ \\
& & Jembrana \\
\hline
\end{tabular}

Pelaksanaan pelatihan permainan Tonnis bagi Guru Penjasorkes SD dan SMP se-Kabupaten Jembrana dilaksanakan pada Jumat, 26 Juli 2013 pukul 08.30 sampai dengan 16.00 wita di GOR SMP Negeri 4 Mendoyo-Jembrana. Adapun jadwal kegiatannya adalah sebagai berikut:

Tabel 03. Jadwal Kegiatan Pelatihan Tonnis bagi Guru Penjasorkes SD dan SMP seKabupaten Jembrana

\begin{tabular}{|c|l|l|}
\hline Waktu(Wita) & \multicolumn{1}{|c|}{ Kegiatan } & \multicolumn{1}{|c|}{ Keterangan } \\
\hline $08.30-09.30$ & Registrasi Peserta dan Snack & $\begin{array}{l}\text { Sie. } \\
\text { Kesekretariatan } \\
\text { dan Konsumsi }\end{array}$ \\
\hline $09.30-10.00$ & $\begin{array}{l}\text { Sambutan Kepala Dikporaparbud Kab. } \\
\text { Jembrana } \\
\text { Pembukaan Pelatihan oleh Ketua LPM } \\
\text { Undiksha }\end{array}$ & Sie. Acara \\
\hline $10.00-11.00$ & $\begin{array}{l}\text { Penyampaian Materi } \\
\text { Sejarah, Fasilitas, Sarana dan Prasarana } \\
\text { Permainan Tonnis }\end{array}$ & Pemakalah \\
\hline $11.00-12.30$ & $\begin{array}{l}\text { Praktek Permainan Tonnis 1: } \\
\text { Teknik Dasar Permainan Tonnis }\end{array}$ & Pemakalah \\
\hline $12.30-13.30$ & $\begin{array}{l}\text { Makan Siang dan Istirahat } \\
\text { Sie Konsumsi }\end{array}$ \\
\hline $13.30-15.30$ & $\begin{array}{l}\text { Praktek Permainan Tonnis 2: } \\
\text { Peraturan Permainan Tonnis dan } \\
\text { Bermain Tonnis }\end{array}$ & $\begin{array}{l}\text { Pemakalah } \\
\text { Penutupan dan Pembagian Piagam }\end{array}$ \\
\hline $15.30-16.00$ & Sie. Acara \\
\hline
\end{tabular}

Peserta pelatihan berasal dari Guru Penjasorkes SD dan SMP se-Kabupaten Jembrana yang dirancang sebanyak 80 orang. Namun, sampai dengan waktu registrasi selesai tercatat sebanyak 61 orang terdaftar sebagai peserta, terdiri dari 40 orang guru penjasorkes SD dan 21 orang guru penjasorkes SMP/MTs. Dalam perencanaan 
kegiatan sesuai dengan jadwal kegiatan, pelatihan akan dibuka oleh Ketua LPM Undiksha, namun karena adanya kegiatan yang tidak boleh diwakilkan di Undiksha maka pembukaan kegiatan dilakukan oleh Kepala Bidang Olahraga mewakili Kepala Dinas Pendidikan, Pemuda, Olahraga, Pariwisata dan Kebudayaan Kabupeten Jembrana. Setelah kegiatan pembukaan langsung dilanjutkan dengan penyampaian materi oleh narasumber Made Agus Wijaya, S.Pd., M.Pd. Selama pelaksanaan kegiatan, komunikasi yang hangat terjalin antara narasumber dan peserta pelatihan. Peserta sangat semangat dan antusias selama kegiatan pemaparan materi dan praktek permainan tonnis. Setelah praktek permainan tonnis dilaksanakan simulasi pertandingan tonnis antar peserta dan sebagai juaranya adalah sebagai berikut:

$$
\begin{aligned}
& \text { Juara I } \quad \text { : I Gst.Ngr. Km. Mahardika + I Nyoman Artono } \\
& \text { (dari SD N } 3 \text { Dangin Tukadaya dan SD N } 1 \text { Dangin Tukadaya) } \\
& \text { Juara II } \quad \text { : I Ketut Winada +I Gusti Ketut Yudhi Suwastika Yasa, S.Pd } \\
& \text { (dari SD N } 2 \text { Pulukan dan SMP Negeri } 5 \text { Mendoyo) } \\
& \text { Juara III : I Nyoman Diatmika, S.Pd. + I Ketut Ariana, S.Pd } \\
& \text { (dari SD N } 5 \text { Berangbang + SD N } 6 \text { Dauh Waru) } \\
& \text { Juara IV : I Made Winarta + I Ketut Udiana } \\
& \text { (dari SD N } 1 \text { Pergung + SD N } 4 \text { Penyaringan) }
\end{aligned}
$$

Pada bagian akhir kegiatan, dilaksanakan kegiatan penutupan pelatihan yang dirangkaikan dengan acara penyerahan hadiah bagi pemenang dan peserta terpilih. Hadiah yang diserahkan berupa perlengkapan permainan tonnis yang terdiri dari 4 (empat) paddle dan bola tonnis. Kegiatan pada tahap penutup dari $\mathrm{P}_{2} \mathrm{M}$ ini adalah membuat laporan akhir pelaksanaan $\mathrm{P}_{2} \mathrm{M}$ dan pengumpulan laporan akhir pelaksanaan $\mathrm{P}_{2} \mathrm{M}$ kepada Unit $\mathrm{P}_{2} \mathrm{M}$ Undiksha.

\section{Penutup.}

Berdasarkan uraian diatas, dapat disimpulkan bahwa: (a) Kegiatan-kegitan yang dirancang dalam $\mathrm{P}_{2} \mathrm{M}$ ini dapat dilaksanakan dengan baik, lancar dan sukses berkat kolaborasi, sinergi dan komunikasi yang efektif antara pihak pelaksana kegiatan (Jurusan Penjaskesrek FOK Undiksha), LPM Undiksha, Pemerintah Kabupaten 
Jembrana, Dikporaparbud Jembrana dan guru penjasorkes SD dan SMP se-Kabupaten Jembrana, (b) Guru Penjasorkes SD dan SMP se-Kabupaten Jembrana memiliki pengetahuan, pemahaman dan keterampilan pelaksanaan permainan tonnis, (c) Guru Penjasorkes SD dan SMP se-Kabupaten Jembrana memiliki pengetahuan dan pemahaman mengenai peraturan permainan tonnis, (d) Kemitraan antara guru Penjasorkes SD dan SMP se-Kabupaten Jembrana, Dinas Pendidikan Kabupaten Jembrana, Kantor Unit Pelaksana Pendidikan se-Kabupaten Jembrana dan Jurusan Penjaskesrek Fakultas Olahraga dan Kesehatan Undiksha dapat terjalin dengan baik dan harmonis.

\section{DAFTAR PUSTAKA}

Lutan, Rusli. 2002a. Asas-Asas Pendidikan Jasmani Pendekatan gerak di SD. Jakarta: Depdiknas-Ditjora.

------.2002b. Asas-Asas Pendidikan Jasmani Pendekatan gerak di SD. Jakarta: Depdiknas-Ditjora

Nurharsono, Tri dan Sri Haryono. 2006. Permainan Tonnis. Semarang: Universitas Negeri Semarang.

Permendiknas Nomor 22 Tahun 2006 tentang Standar Isi Kurikulum.

Undang-Undang Republik Indonesia Nomor 20 Tahun 2003 tentang Sistem Pendidikan Nasional. 